\title{
Deixis Role as an Index of Style: A Comparative Corpus Stylistics Analysis of Self, Pakistani and Other Translators
}

\author{
Khadija Tul Kubra ${ }^{1}$, Ayesha Murtza ${ }^{1} \&$ Muhammad Asim Mahmood ${ }^{1}$ \\ ${ }^{1}$ Department of English Literature and Linguistics, Government College University, Faisalabad, Pakistan \\ Correspondence: Khadija Tul Kubra, Department of English Literature and Linguistics, Government College \\ University, Faisalabad, Pakistan. E-mail: khadija_101@hotmail.com; ayeshacheema346@gmail.com; \\ masimrai@gmail.com
}

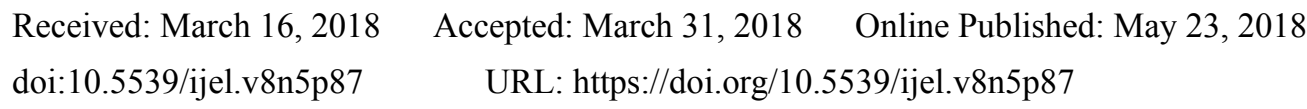

\begin{abstract}
Deixis are the linguistic expressions which are used for the reference within the context and out of the context to share knowledge. These are functional keys for contextual coherence and for strong involvement of interlocutors. In this dissertation, role of deixis are interpreted with reference of three different categories of novels; Pakistani novels, other translated, and self-translated novels. The aim of this research is to extract the style difference due to the use of deixis as a style indicator in other and self-translated novels in comparison with non-translated novels. Further, we will try to find out how the use of different types of deixis effects on the context of the text. Generally it has witnessed that the other and self-translators are different in their styles. The reason behind such difference is that the self-translator has more freedom while translating their own novels for other audience. For analysis, in total nine novels are selected, three novels of one category and in total three categories are involved. This research adopted the quantitative approach and for analysis corpus software tool, AntConc is used. Whole data is tagged by POS tagger and manually as well, than interpreted through AntConc. The results of this research indicate that the Self translated novels used more deixis and have more simple and direct language then the others translated categories. In these novels the first person and second person communication is more oriented. Similarly other deixis expressions as time, past tense and special deixis are more referred which make language explicit.
\end{abstract}

Keywords: context, deixis, novels, translation, self-translator, other-translators

\section{Introduction}

Deixis are the discourse devise to operate the communication in actual contextual meanings. The person who is standing out of context could not understand complete meanings as compare to the person who is the part of the background of the context or know about context (Goodwin \&Duranti, 1992). Goffman (1974) said that the person who is familiar with context could analyze and interpret in actual pragmatics and intentions. Deixis are the tools of the discourse analysis. The deictic are also share co-cultural expressions, the already discussed topic, the background knowledge, social norms and what speaker intended to said their illocutionary act in communication. All background shared knowledge and unsaid utterances are explicit by deictic expressions. Deixis comprises "those features of language which refer directly to the personal, temporal or locational characteristics of a situation within which an utterance takes place" (Crystal, 2003, p. 127). Deixis are the linguistic devices which create the linkage between the present talk and previous context (Hanks, 1992; Lyons, 1977; Hanks, 2011).

Deixis are the device of discourse which develops relation among the used context and the used language for that context. In this way the deixis help to understand discourse and the behind situation of discourse. What are the effecting reasons of used discourse? The word "deixis" is borrowed from Greek language which means "to show" or to indicate, that's why deixis are the words that point the target situation and their happenings. Yule (1996) divided the contextual references into three types of gestures, symbols, and deixis.

Gestures are the body language that varies situation to situation. These gestures have their contextual meanings. The person, who closely knows the function of gestures in that particular context, will be able to understand the meaning of the speaker. "Symbolic" means the use of such deictic expressions which are associated with connotative meanings, derived from the specific context. These meanings are only understood with enough 
cultural knowledge. Symbolic meanings differ from situation to situation. Third is anaphoric reference. These references occur within the same context. The outsider of the context can understand the under laying meanings, if re-consult the previous uttered or written context. These references are co-occurring within the current context. The anaphoric reference is actually the deictic expressions in the language. Stephan Levinson presented the theory of deixis having three categories; personal, place, and time.

\section{Literature Review}

Deixis are the linguistics devices that use to develop linking language and make any context specific towards its original situation. In past, a lot of work is done in this field. Linguistically deixis are known as deictics and deictic expressions or indexical expressions. According to the Huang (2007), there are four categories of deixis; demonstratives, personal pronoun, place, and time. Varua (2014) said that there are three main categories of deixis; personal, spatial and temporal. In this research Huang's model is used. Huang define the deixis' center as the "I, Here, and Now", which refer to the speaker pronoun, time of event, and place of communication.

Yule (1996) further define the category of personal pronoun into three divisions; first person "I", second person "you" and third person "he, she, and it". Filmore (1997) defines the spatial or location deictic into two sets; the adverbial "here and there" and demonstrated "this and that". These two sets of deictic expressions use to indicate two different positions in context distant position as "that and there" and close position as "this and here".

Levinson (1983) works on the temporal deixis that indexes the speaker relation in time continuum. These deictic include adverbs and adverbials such as yesterday, today and tomorrow (adverbs) and last Monday, this afternoon, and next year (time adverbials). Time adverbials also include tense backward reference which most importantly deals past tense in the context. Time deixis use to show the share context among speakers (Ruhlemann, 2007).

There are four types of deixis in English; personal, place, time and past tense. In past studies most of the researchers check the effect of deixis in different writing and speaking genres. In these researches any one of these types is interpreted. In present study all the respected types of deixis are supposed to interpret in novel writing to check the transitivity effect by native writers, Pakistani writers and the self-translated novels.

The three types of deixis; personal, temporal and locational are investigated in the political speeches. In this work Adetunji (2006), the role of deictic expressions are measured which indicate that the deixis are used to show politicians' personal association with particular ideology and they associate their thought with collective view of their partners and affiliated community.

One stylistic inspection is done in Japan in which 27 Japanese Prime Ministers speeches are analyzed. In this research the deictic expression is compared which one is more used to convey their hidden expressions. The prime minister speeches are compared with common person data from online corpora and results indicate that Prime Minister Speeches' data involve more personal and individual deixis than the writing sample of common users (Suzuki \&Kageura, 2008).

There are three types of personal deixis that participate in communication. The speaker is first person deictic that directly convey the message. The speaker participates in conversation as the center of the deictic. The second personal deictic is addressee and third personal deixis are referential person who are not the speaker or direct addressee. The referent deixis are not directly part of the situation. According to the Levinson (1996) the personal deixis are contextual tools that determine the role of participants in speech community and establish the power relation. Levinson not only point the individuals of conversation, he used the term personal deixis for differentiating the role of participants. The personal deixis are further elaborated in three types. First personal deixis are reference tool to point the speaker and current center of the conversation. Then second person deixis are the tool for speaker, who uses it to refer the addressee to shift the communication side. The third person deixis is last type of personal deixis. The third person deixis use to point the person that is not present and not the part of communication, the person out of the context (Levinson, 1983).

Allott deny the third person pronoun as the deictic category because it is not the center as speaker or addressee but in his exploratory work he also accept that truth the third person deixis are most frequent type as deictically.

The spatial deixis indicate the location of the participants, where communication event occur (Levinson, 1983). These deixis differentiate proximal and distal positions of the participants.

Temporal deixis are the time pointer during the communication. According to the Levinson the temporal deixis are the pointer of actual utterances rather than the coding of the utterance in speakers' mind (Levinson, 1983).

\section{Research Questions}

1) How deixis effects on the meanings of the context? 
2) What are the differences among the Pakistani writing, other translators' and self-translated writings?

\section{Methodology}

\subsection{Corpus Implemented Design}

I collected nine novels data, three from Pakistani writers, three from self-translators and three from other translators.

In previous researches deixis are interpreted qualitatively and no proper quantitative method is designed. In the light of past conducted researches I developed list of deixis, for quantitative study of this field, which is given below:

Table 1. Checklist for different types of deixis

\begin{tabular}{|c|c|}
\hline Personal deixis & \\
\hline \multirow[t]{4}{*}{ First person } & I \\
\hline & $\mathrm{Me}$ \\
\hline & My \\
\hline & Mine \\
\hline \multirow[t]{3}{*}{ First person plural (inclusive or exclusive) } & We \\
\hline & Us \\
\hline & Our \\
\hline \multirow[t]{3}{*}{ Second } & You \\
\hline & Your \\
\hline & Yours \\
\hline \multirow{5}{*}{ Third person } & She \\
\hline & $\mathrm{He}$ \\
\hline & It \\
\hline & They, their, them \\
\hline & Everybody, some, those, these \\
\hline \multicolumn{2}{|l|}{ Place or Location deixis } \\
\hline \multirow[t]{2}{*}{ Adverbs } & Here \\
\hline & There \\
\hline \multirow[t]{3}{*}{ Demonstrated } & This \\
\hline & There \\
\hline & That \\
\hline \multicolumn{2}{|l|}{ Time or temporal deixis } \\
\hline \multirow[t]{3}{*}{ Adverbs } & Yesterday \\
\hline & Today \\
\hline & Tomorrow \\
\hline \multirow[t]{4}{*}{ Time adverbials } & Last Tuesday \\
\hline & This afternoon \\
\hline & Then, now, soon \\
\hline & Last year \\
\hline \multirow[t]{2}{*}{ Tenses } & Past tense for storytelling and history \\
\hline & Present for any present narration and future indications \\
\hline \multicolumn{2}{|l|}{ Past tense } \\
\hline Simple past tense & Was, were, did, had \\
\hline Past stative & "Ed" forms \\
\hline Past participle & Past Perfect and past passive \\
\hline
\end{tabular}

\subsection{Data Collection}

Data has designed in various steps for analysis. Printed text and OCR software is used to convert written text into soft form. Nine novels are collected from three variable categories. Nine novels are used and three variable categories are generated; comprising of three novels in each. Data collection is completed in eight steps. 


\subsubsection{Phases of Data Collection}

At first stage, written data is converted into soft form. At second step, data is converted into text files for edition and, then removed the data for extracting extra information rather than actual data. This editing insures more validity of data. At the third stage data has been analyzed.

\subsection{Data Analysis}

For analysis purposes four softwares have been used. First online software is used to convert written files into soft form. Secondly, use AntFileConverter 1.2.0 to convert word file into the text file. Third, I tagged all files with POS tagger. Forth, software is used AntConc3.2.4w to find out the frequencies.

To measure the overall frequencies in three categories; open the AntConc software and select the option "open file" from top left side option "file". Then load all the three tagged text files of the self-translated novels. In the next step, already denoted tags of different deixis by POS tagger are entered into search bar. In this way frequencies of deixis are extracted of each category. In this way all deixis are find out from each category of novels.

In second step frequency table is draw of all three categories side by side to compare the similarities and differences among all types of writings.

\subsection{Constraints on Corpus Design}

In my corpus design time and gender variables are not controlled. This study investigates differences of writing styles by changing the origin of authors. How different nationalities effects on the use of style.

\section{Analysis and Discussion}

Talk, taken out of context, has little meaning. For those who participate in it, talk reveals its full and specific meanings only against the "background" of the context in which it occurs. To evaluate background of the participants there are four types of deixis. These are personal deixis, temporal deixis, place deixis and past tense deixis.

\subsection{Personal Deixis}

Personal deixis are used to express the role of interlocutor and participant in speech act (Huang, 2007). Personal deixis determine the position of different participants in an event. How speaker and addressee shift their communications turns. It also establishes the relationship about more talkative speaker and addressee. In this research three different translators of novels are analyzed. In these three categories novels by self-translator are more first person oriented.

Table 2. Frequencies of personal deixis in three different categories

\begin{tabular}{llll}
\hline First person deixis & Other translator & Pakistani translator & Self-translator \\
\hline 1st person singular objective personal pronoun (PPIO1) & 566 & 904 & 1202 \\
1st person plural objective personal pronoun(PPIO2) & 95 & 139 & 270 \\
1st person singular subjective personal pronoun (PPIS1) & 1962 & 2267 & 4233 \\
1st person plural subjective personal pronoun (PPIS2) & 350 & 161 & 700 \\
possessive pronoun, pre-nominal (APPGE) & 3058 & 3445 & 10897 \\
nominal possessive personal pronoun (PPGE) & 25 & 72 & 114 \\
Total: & 6056 & 6084 & 11743 \\
Normalized frequencies & 25.810 & 25.506 & 23.978 \\
Percentile: & 1.69 & 2.51 & 3.38 \\
Second person deixis & & & \\
2nd person personal pronoun (PPY) & 1064 & 537 & 3394 \\
Normalized frequencies & 4.535 & 2.251 & 6.930 \\
Percentile: & 0.30 & 0.22 & 0.62 \\
Third person deixis & & & 2847 \\
3rd person singular neuter personal pronoun (PPH1) & 817 & 679 & 2345 \\
3rd person sing. objective personal pronoun (PPHO1) & 722 & 774 & 1058 \\
3rd person plural objective personal pronoun (PPHO2) & 265 & 218 & 7719 \\
3rd person singular subjective personal pronoun (PPHS1) & 1766 & 1546 & 1752 \\
3rd person plural subjective personal pronoun (PPHS2) & 394 & 284 & 9615 \\
Total: & 3964 & 3501 & 19.633 \\
Normalized frequencies & 16.894 & 14.677 & 2.77 \\
Percentile & 1.11 & 1.45 & \\
\hline
\end{tabular}


In these three categories of novels, first person deixis are more frequent. It is also indicate that the dialogues are happening in formal situation. First person deixis show the formal reference of interlocutor as, "I" and "we". In these three categories of novels first person are more frequent than the other personal references. As in novels story revolve around characters and writer solve the story conflict by dealing with the state of the mind of individual character. The use of first person also shows the same function. The first person deixis also shows the freedom of the character's spoken. In collective first person pronoun, 1st person singular subjective personal pronoun (I) is much more frequent in all other first person deixis which show that character are talking about himself / herself. So the speeches are self-oriented. 1st person singular objective personal pronoun (me) is second more frequent deixis of first person, which is again referring to the self-oriented context of the speech. On the other hand "we" and "us" are the less frequent as compared to the "I" and "me". "We" and "us" show that in speech context both speaker and listener sides are involved. The use of deixis changes with the variation in context. Similarly, the frequencies of all three different writers are different. The novels of self-translator writers are seem to be more formal, because the frequency of first person deixis are 23.978 and frequencies of Pakistani writing and other translators are 25.506 and 25.810 respectively. The cultural norms and the way of talking in normal life as formal, less formal and informal effect on the use of personal deixis, that show how we address to the other in multiple contexts.

Personal deixis have no permanent status in nature and in extra-linguistic world. These get place according to the situation and state of mind of the speaker. Deixis give the prominence state some of the character and less prominence state to some of them. It also develops the contrast among characters for reader's understanding.

\subsection{Place or Locational Deixis}

Place deixis are the indication about the location of the speech event. These locational indication in speech event refer toward some relates objects, or about some reference points, or some time refer towards the position of the speaker at the speaking time (Levinson, 1985, p. 79). Place deixis are responsible for the position of the participant and role in speech event (Huang, 2007). Allot (2010) said that place deixis are known as spatial deixis which involve adverb i.e., here, there and demonstrative i.e. this and that.

Table 3. Frequencies of place deixis in three different categories

\begin{tabular}{llll}
\hline Place deixis & Other translator & Pakistani translator & Self-translator \\
\hline & 1631 & 661 & 4284 \\
normalized frequencies & 6.951 & 2.771 & 8.747 \\
\hline
\end{tabular}

As above interpretation of personal deixis indicate that self-translated novels have more direct conversation. In self translated novels more spatial deixis are used because more direct conversation is involved. In Pakistani translated and other translated novels as third person narration are involved in almost equal ratio, same in case of spatial deixis. These novels involve less spatial deixis than self-translated novels.

These deixis are also use for keeping the focus of communication participants towards speech event, act, and objects. These deixis have functions to display context of the situation (Lyons, 1968;Fillmore, 1997 \&Marchello, 1995). Haviland (2000) said these demonstrative determine the position; where someone is with regard of addressee in target context. Positional deixis also ply many pragmatics functions in context. Spatial deixis involve functions of contextual reference, report the involved identities, location, and the direction of intentions of speakers and listener to fulfill other contextual functions.

\subsection{Temporal Deixis}

Temporal deixis are used to define the event sequence and inter relationship of the speech events. Time deixisinvolve the time adverbials and tenses (Verhagen et al., 2009; Verhagen et al., 2010). Signals of temporal deixis work to establish the existential relation between two events, state and interval relations. In some situations temporal deixis have dual references; which are mutually inter related.

Table 4. Frequencies of temporal deixis in three different categories

\begin{tabular}{llll}
\hline Temporal deixis & Other translator & Pakistani translator & Self-translator \\
\hline & 643 & 431 & 2247 \\
normalized frequencies & 2.740 & 1.807 & 4.588 \\
\hline
\end{tabular}


In temporal deixis anaphoric expressions as "later, or after" use to develop strong contextual bounding and participant take overlook of whole event (Reichenbach, 1947; Dowty, 1979). Some deixis are signals of new argument and some are for backward reference.

\subsection{Past Tense}

Time is an abstract experience that we have only by being conscious of the present moment. This experience consists of a set of our present moments, which makes a ceaseless flow of time. We can say that some event happened (a past event) because we are conscious of the present moment when we are speaking, and see the temporal relation from the stand point of the present moment. Thus, tense, which is conceptualized in language, has to be deictic.

Table 5. Frequencies of past tense deixis in three different categories

\begin{tabular}{llll}
\hline Past tense & Other translator & Pakistani translator & Self-translator \\
\hline Past tense (was, were, did, had) (VBDR, VBDZ, VDD, VHD) & 2920 & 4618 & 10883 \\
Past stative (VVD) & 3698 & 3844 & 18137 \\
Past participle (VHN) & 36 & 39 & 69 \\
Total: & 6654 & 8501 & 29089 \\
normalized frequencies & 28.358 & 35.639 & 59.396 \\
\hline
\end{tabular}

According to Nunberg (1993), the meaning of indexical expressions consists of three components: the deictic component, the relational component, and the classificatory component. Thus, the meaning of yesterday is "the calendar day" (classificatory component) that "precedes" (relational component) "the time of speaking" (deictic component).Thus, yesterday differs from tomorrow in terms of its relational component, and from last year (yesteryear) in terms of its classificatory component (Nunberg, 1993, p. 9). In these works the self-translator writings have more past tenses, which indicate that these writings are more sequential.

Past tense signals that the situation is viewed as bounded temporally and indicate a situation which occurred before the moment of speech. A simple past resembles a perfective in that it is the tense of narration of sequences of past event.

The past tense have very drastic roll in the interpretation of the meanings with reference of specific context. The past tense also indicates the ration of the shared knowledge among the interlocutors. In present three samples, self-translated novels have strong link among past happening. This category of novels has more personal pronouns and special deixis which represent that the communication is more direct and have relation with past happening as well.

\section{Conclusion}

This study aims to investigate the function of deixis in different translated novels with comparison of non-translated novels. The results of three categories of novels are indicate that self-translated involve maximum number of deixis expressions as compare to the other translated and Pakistani novels. The other translated novels are more contextual bounded than the Pakistani novels. Because in Pakistani novels minimum past tense reference, time and special reference are used, while in other novels these deixis are more in number which create strong link within the context. The other and self-translated novels are free to use deictic expressions in their writing and use simpler and reader oriented language.

This research helps to differentiate different writing styles and effect of usage of deixis in context. Collectively, the language of self-translated writing is formal and has strong coherence in their context. These writings have more use of past tense, and personal deixis. These features make the self-translated novels more thematically attractive and structured language. In comparison of other two writers' work, the other translator writers' work has more cohesion. Other translator novels have more special and personal deixis than the Pakistani (non-translated) writings.

So, this research is beneficent to understand the piece of literature as well as for the pedagogical use. Experienced use of deixis enables the learners to make their writings more comprehensive and structured one.

The further research in this field is required because whole process of the field has not interpreted through corpus before this work. In this research all categories of deixis are discussed at surface level. So, further research should explore single categories of deixis in details. 


\section{References}

Adetunji, A. (2006). Inclusion and exclusion in political discourse: Deixis in Olusegun Obasanjo's speeches. Journal of Langugaes and Linguistics.

Allott, N. (2010). Key terms in pragmatics. London: Continuum International.

Crystal, D. (2003). A Dictionary of Linguistics and Phonetics (Vol. 5). Blackwell: Oxford.

Dowty, D. R. (1979). Word meaning and Montague grammar: The semantics of verbs and times in generative sematics and in Meaning's PTQ. Springer. https://doi.org/10.1007/978-94-009-9473-7

Fillmore, J. C. (1997). Lectures on Deixis. Stanford (USA).

Goffman, E. (1974). Frame Analysis: An Essay on the Social Organization of Experience. New York: Harper and Row.

Goodwin, C., \& Duranti, A. (1992). Rethinking Context: Language as an Interactive Phenomenon. Cambridge: Cambridge University Press.

Hanks, W. F. (1992). The indexical ground of deictic reference. Cambridge: Oxfoed Univerisy Press.

Haviland, B. J. (2000). Pointing, Gesture Spaces, and Mental Maps. In D. McNeill (Ed.). Cambridge: Cambridge University Press. https://doi.org/10.1017/CBO9780511620850.003

Levinson, S. C. (1983). Pragmatics. Cambridge: Cambridge University Press.

Levinson, S. C. (1992). Pragmatcs. Cambridge: Cambridge University Press.

Lyons, J. (1977). Semantics (Vols. I, 11). Cambridge: Cambridge University Press. https://doi.org/10.1017/CBO9781139165693

Moon, V., Ronal, G., Ford, S., Ple, M. E., Jorge, M., \& Jorge, P. (2009). The TempEval Challenge: Identifying Temporal Relations in Text.

Reichenbach, H. (1947). Elements of Symbolic Logic. New York: The Macmillan Compny.

Ruhlemann, C. (2007). Conversation in Context: A Corpus-Driven Approach. London: Continum International.

Suzuki, T., \& Kageura, K. (2010). Stylistic analysis of Japanese Prime Ministers' Diet addresses. In T. Tokunaga \& A. Ortega (Eds.), LKR 2008. Paper presented at the Third International Conference on Large-Scale Knowledge Resources, Tokyo (pp. 318-325).

\section{Appendix}

\section{Pakistani Novels:}

Written by Pakistani authors who write them directly in English language.

\section{Other Translators:}

Novels which are written in Urdu language and later on other Pakistani writers translated it into English.

\section{Self-translated:}

Novels which are written in Urdu language and later on translated by the same author into the English language.

\section{Copyrights}

Copyright for this article is retained by the author(s), with first publication rights granted to the journal.

This is an open-access article distributed under the terms and conditions of the Creative Commons Attribution license (http://creativecommons.org/licenses/by/4.0/). 